\title{
Cochylimorpha Razowski (Lepidoptera: Tortricidae: Cochylini) in China: one new species, three newly recorded species and description of the female of three species
}

\author{
Yinghui Sun \& Houhun $\mathrm{Li}^{*}$
}

\begin{abstract}
Sun, Y. \& Li, H. 2013: Cochylimorpha Razowski (Lepidoptera: Tortricidae: Cochylini) in China: one new species, three newly recorded species and description of the female of three species. - Entomol. Fennica 24: 193-203.

Cochylimorpha subnomadana sp. n., from Mt. Liupan, Ningxia, China is described as new. Cochylimorpha declivana (Kennel, 1901), C. halophilana clavana (Constant, 1888), and C. meridiolana (Ragonot, 1894) are newly recorded for China. The previously unknown females of $C$. conankinensis $(\mathrm{Ge}$, 1992), C. maleropa (Meyrick, 1937), and C. razowskiana Kuznetzov, 2005 are described for the first time. Photographs of the adults and genitalia are provided, along with a key to all the described Chinese Cochylimorpha species.
\end{abstract}

Y. Sun \& H. Li*, College of Life Sciences, Nankai University, Tianjin 300071, China; *Corresponding author e-mail: lihouhun@nankai.edu.cn

Received 5 January 2013, accepted 3 April 2013

\section{Introduction}

Cochylimorpha was established by Razowski (1959) with Cochylis favillana Staudinger, 1859 as the type species. Brown (2005) listed 89 species worldwide, with 83 described from the Palaearctic Region, five from the Oriental Region, and one from the Neotropical Region. Subsequently, Kuznetzov (2005) proposed a new replacement name Cochylimorpha razowskiana for Cochylimorpha pallens (Kuznetzov, 1966), and Razowski (2005) described one new species from Afghanistan and another from Tibet, China (Razowski 2006). Aarvik (2010) described one new species and proposed three new combinations from East Africa. At present, Cochylimorpha comprises 95 species worldwide (Gilligan et al. 2012).

In China, Cochylimorpha was treated as Stenodes Guenée, 1845 by Liu \& Li (2002), who compiled a list of 15 Chinese species. Razowski
(2006) subsequently provided an annotated list of 20 known Chinese species, excluding C. bipunctata (Bai et al., 1996) and C. simplicis (Bai et al., 1996). Prior to this study, 23 species were recorded in China.

In this paper, we describe one new species and the previously unknown females of three other species, and present the first records of three species for China.

\section{Material and methods}

Specimens examined were collected using light traps. Terminology for morphological features follows Razowski (1987). Genitalia dissection and slide-mounting methods follow Li (2002). Images of the adults were taken with a Nikon D300 digital camera with a macro lens, and images of the genitalia were captured using an Olympus C-7070 digital camera attached to an 
Olympus BX51 microscope. All the specimens examined are deposited in the Insect Collection, College of Life Sciences, Nankai University, Tianjin, China. Type locality is abbreviated as TL.

\section{Taxonomy}

\subsection{Cochylimorpha Razowski, 1959}

Stenodes Guenée, 1845. Annales de la Soci Entomologique de France, 2(3): 298. - Type species: Cochylis elongana Fischer von R lerstamm, 1839. [preoccupied]

Cochylimorpha Razowski, 1959. Polskie Pismo Entomologiczne, 29: 440. - Type species: Cochylis favillana Staudinger, 1859.

Bipenisia Razowski, 1960. Polskie Pismo Entomologiczne, 30: 300. - Type species: Cochylis jucundana Treitschke, 1835. [subgenus of Stenodes]

Bleszynskiella Razowski, 1960. Polskie Pismo Entomologiczne, 30: 303. - Type species: Orthotaenia alternana Curtis, 1831. [subgenus of Euxanthoides]

Eustenodes Razowski, 1960. Polskie Pismo Entomologiczne, 30: 297. - Type species: Euxanthis dorsimaculana Preissecker, 1908. [subgenus of Stenodes]

Euxanthoides Razowski, 1960. Polskie Pismo Entomologiczne, 30: 302. - Type species: Tortrix straminea Haworth, 1811.

Parastenodes Razowski, 1960. Polskie Pismo Entomologiczne, 30: 299. - Type species: Cochylis meridiana Staudinger, 1859. [subgenus of Stenodes]

Paraxanthoides Razowski, 1960. Polskie Pismo Entomologiczne, 30: 304. - Type species: Tortrix (Cochylis) chamomillana HerrichSch fer, 1851. [subgenus of Euxanthoides]

Substenodes Razowski, 1960. Polskie Pismo Entomologiczne, 30: 298. - Type species: Cochylis pontana Staudinger, 1859. [subgenus of Stenodes]

Diagnostic characters. Adults small to medium size; sexual dimorphism in some species expressed in the forewing shape, narrower in male than in female; forewing with all veins separate, basal distance between $R_{1}-R_{2}$ less than between $\mathrm{R}_{2}-\mathrm{R}_{3}, \mathrm{R}_{5}$ to apex; hindwing in male without costal fold, Rs and $\mathrm{M}_{1}$ stalked or arising from the same point, $\mathrm{M}_{3}$ and $\mathrm{CuA}_{1}$ stalked or arising from the same point; hindwing in female usually with three spines in the frenulum. In male genitalia, uncus and gnathos absent; socius decumbent, connected with distal part of tegumen basally; median process of transtilla with tiny spines distally; vinculum separated ventrally; and phallus slender or stout. In female genitalia, papilla analis slender; ductus bursae usually sclerotized and distinct from corpus bursae; ductus seminalis arising from posterior part of corpus bursae; and corpus bursae usually sclerotized and internally covered with spines.

Biology. In the Palaearctic Region there are two generations yearly, probably three in the south, and hibernation occurs in the larval stages. The larvae utilize mainly Artemisia species (Asteraceae), often feeding in the seeds, stems, and roots (Razowski 1987). Numerous species are bound in open, dry biotopes, e.g. sands and various xerotherms; many species occur in the steppes (Razowski 2009).

Distribution. The 95 described species of Cochylimorpha are distributed worldwide, mainly in the Oriental and Palaearctic regions, with much fewer species in the African and Neotropical regions.

\subsection{Key to the Chinese species of Cochylimorpha based on morphology of adults and male genitalia}

1. Forewing without a marking (Fig. 1d) C. meridiolana

- Forewing with markings 2

2. Forewing without subapical fascia 3

- Forewing with subapical fascia 6

3. Median fascia of forewing absent on costal margin (Razowski 1970: Pl. 5, Fig. 45)

C.jaculana

- Median fascia of forewing present on costal margin

4. Forewing without a spot on distal half of costal margin (Fig. 1b) C. declivana

- Forewing with spots on distal half of costal margin 
5. Forewing with one spot on distal half of costal margin (Razowski 1970: P1. 9, Fig. 90)

C. amabilis

- Forewing with several spots on distal half of costal margin (Razowski 1977: P. 36, Fig. 3)

C. nipponana

6. Forewing with a longitudinal band (Liu \& Li 2002: Pl. I, Fig. 10)

C. gracilens

- Forewing without a longitudinal band 7

7. Median fascia of forewing absent on dorsum (Razowski 1970: P1. 6, Fig. 60) C.nomadana

- Median fascia of forewing present on dorsum

8. Forewing with median fascia and subapical fascia connected anteriorly

9

- Forewing with median fascia and subapical fascia not connected anteriorly 13

9. Phallus covered with tiny teeth distally (Fig. 3c)

C. razowskiana

- Phallus not covered with tiny teeth distally 10

10. Phallus with one cornutus (Fig. 2a) C. subnomadana $\mathbf{s p .} \mathbf{n}$.

- Phallus with two cornuti 11

11. Phallus with one straight and one undulate cornuti (Razowski 1970: P1. 44, Fig. 55)

C. nankinensis

- Phallus with two straight cornuti

12. Two cornuti equal in length (Fig. 3a)

C. conankinesis

- Two cornuti with longer one about two times length of shorter one (Fig. 3b) C. maleropa

13. Phallus divided into two parts on distal half (Razowski 1970: Pl. 56, Figs. 99 ${ }_{1-2}$ )

- Phallus not divided on distal half C. emiliana

14. Sacculus with terminal process, phallus slender

- Sacculus without terminal process, phallus stout

15. Phallus bifurcate into two small teeth at the apex

- Phallus not bifurcate at the apex

16. Phallus not covered with tiny teeth distally and bearing two cornuti (Razowski 1970: Pl. 55, Fig. 95) C. lungtangensis

- Phallus covered with tiny teeth distally and bearing one cornutus (Razowski 1970: Pl. 53, Fig. 94)

C. alticolana

17. Median process of transtilla concave on posterior margin, phallus with cornuti (Liu \& Li
2002: Pl. LIV, Fig. 7)

C. cuspidata

- Median process of transtilla truncate on posterior margin, phallus without cornutus (Razowski 1970: P1. 55, Figs. 96 ${ }_{1-3}$ )

C. fuscimacula

18. Phallus with one cornutus 19

- Phallus with two cornuti 23

19. Sacculus with a tiny spine distally (Razowski 1970: Pl. 50, Figs. $80_{1-2}$ ) C. perturbatana

- Sacculus without a tiny spine distally 20

20. Median process of transtilla rounded on posterior margin 21

- Median process of transtilla slightly concave on posterior margin

22

21. Sacculus about $1 / 2$ length of costa (Fig. 2c)

C. halophilana clavana

- Sacculus slightly shorter than costa (Razowski 1970: P1.43, Fig. 54) C.cultana

22. Cornutus a thick thorn, about $1 / 3$ length of phallus (Razowski 1970: P1. 43, Fig. 53)

C. asiana

- Cornutus a tiny spine (Bai et al. 1996: P. 192, Figs. 4-4a)

C. bipunctata

23. Two cornuti equal in length 24

- Two cornuti with longer one about two times length of shorter one 25

24. Phallus almost as long as valva (Razowski 1970: Pl. 52, Fig. 87) C. isocornutana

- Phallus longer than valva (Bai et al. 1996: P. 192, Figs. 3-3a) C. simplicis

25 . Distal half of valva gradually narrowed to apex (Razowski 1970: P1. 53, Figs. $88_{1-2}$ )

C. hedemanniana

- Distal half of valva extremely narrow, almost same width as costa (Razowski 2006: P. 122, Figs. 1-2)

C. yangtseana

\subsection{Cochylimorpha subnomadana sp. $\mathbf{n}$. Figs. 1a, 2a}

Type material. Holotype $\overbrace{}^{\Uparrow}$ : China, Qiuqianjia Forest Farm, Mt. Liupan (3542’N, $\left.106^{\circ} 11^{\prime} \mathrm{E}\right)$, Ningxia Hui Autonomous Region, 1,700 m, 1.VII.2008, leg. Shulian Hao and Zhiwei Zhang. (Genitalia slide No. SYH11525).

Description. Adult (Fig. 1a) with wingspan $14.0 \mathrm{~mm}$. Head with vertex and frons yellowish white. Antenna yellowish brown, mixed with brownish black scales. Labial palpus slender, 

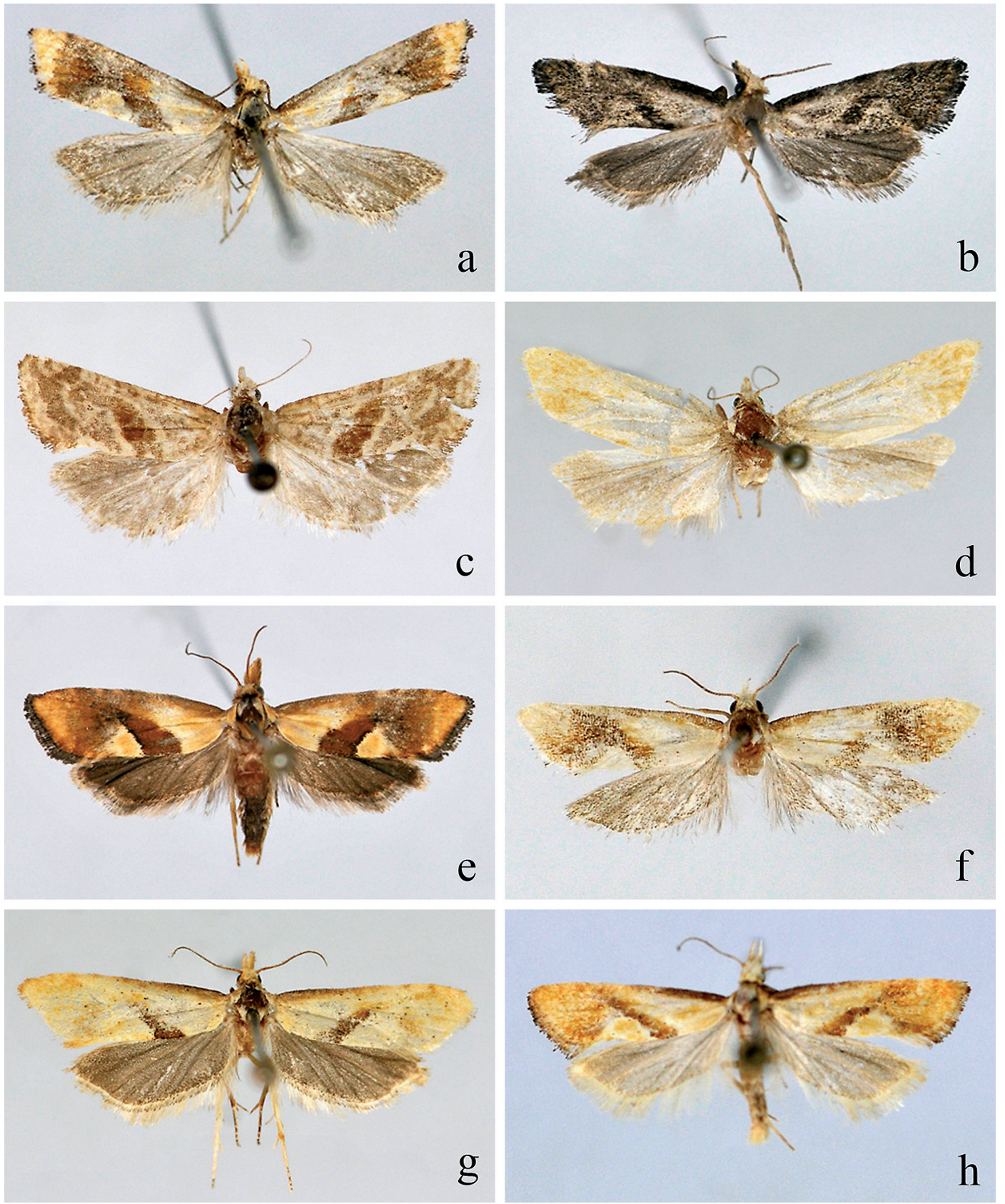

Fig. 1. Adults of Cochylimorpha spp. - a. C. subnomadana sp. n., holotype, male. - b. C. declivana (Kennel), male. - c. C. halophilana clavana (Constant), female. - d. C. meridiolana (Ragonot), female. - e. C. conankinensis (Ge), female.-f. C. maleropa (Meyrick), male. - g. C. maleropa (Meyrick), female. - h. C. razowskiana Kuznetzov, male.

about 2.5 times length of diameter of compound eye, yellow with sparse brownish black scales on outer surface, yellowish white on inner surface. Thorax yellowish white; tegula grayish brown. Forewing narrow, costal margin straight, termen oblique. Ground color yellowish white; costal margin with a yellowish brown stripe on basal $1 / 4$, sparsely mixed with brownish black; median fascia extending from middle of costal margin obliquely inward to basal $2 / 5$ of dorsum, grayish 


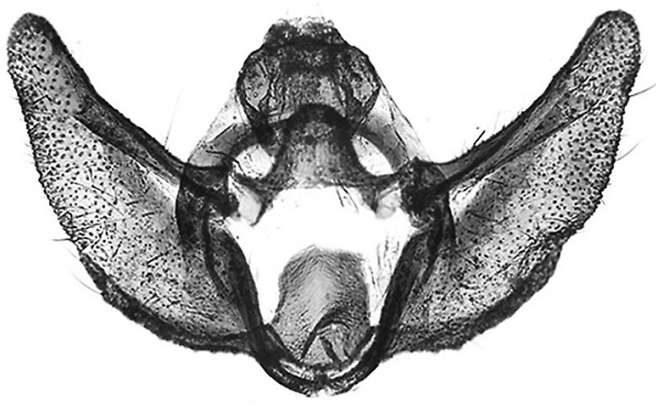

a
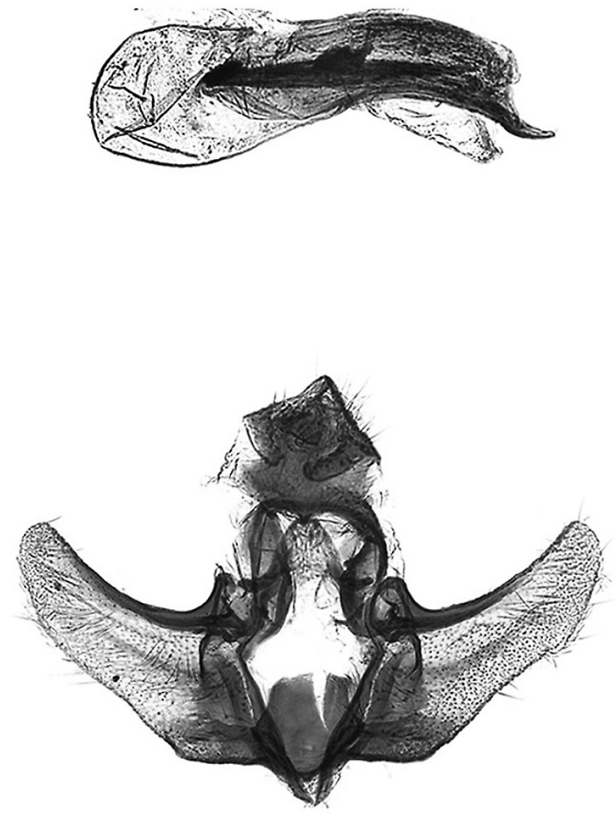

$\mathrm{C}$

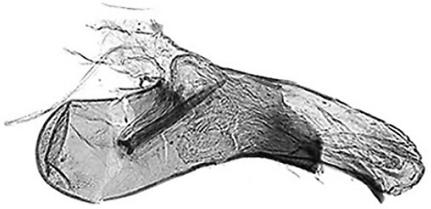

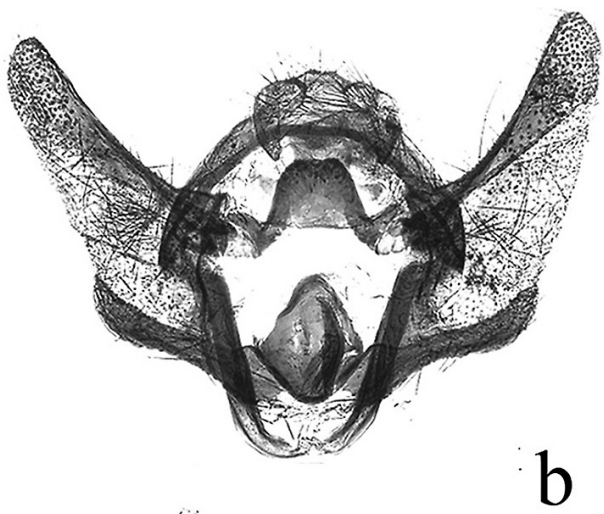
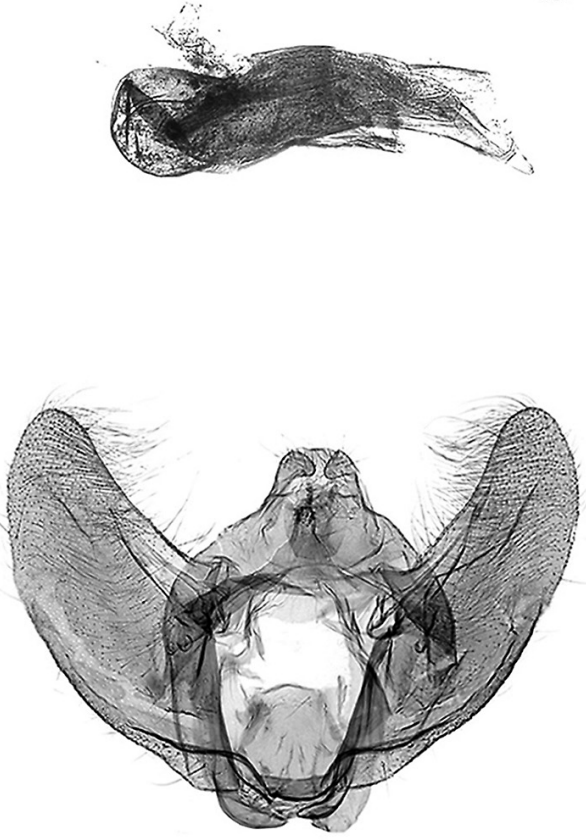

d

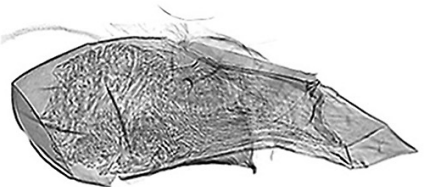

Fig. 2. Male genitalia of Cochylimorpha spp. - a. C. subnomadana sp. n., holotype, slide no. SYH11525. - b. C. declivana (Kennel), slide no. SYH11472. - c. C. halophilana clavana (Constant), slide no. SYH11333. - d. C. meridiolana (Ragonot), slide no. SYH11109.

brown, densely covered with ochreous yellow scales from a short distance below costal margin to lower margin of cell, forming an ill-defined spot, tinged with ochreous brown from lower margin of cell to dorsum; subapical fascia broad, extending straight from before apex on costal margin to before tornus, grayish brown, tinged with ochreous yellow on its outer $2 / 3$ except on costal and dorsal margins, its inner margin protruded and touching outer margin of median fascia on anterior half, forming a triangular yellowish white patch on dorsum; cilia basally grayish white, distally grayish black. Hindwing and cilia gray. Fore- and midlegs yellowish brown, mixed 
with brownish black; hindleg brownish black. Abdomen brownish black.

Male genitalia (Fig. 2a). Socius decumbent, narrowed from base to pointed apex. Valva with outer margin obliquely straight; costa gently arched; median process of transtilla broad, trapezoidal, distal part with tiny spines, apex rounded. Sacculus narrow, heavily sclerotized, slightly shorter than costa. Vinculum slender. Juxta nearly oval. Phallus slightly longer than valva, basal $2 / 5$ expanded, sharply narrowed at distal $1 / 7$, forming a thorn-shaped distal process; cornutus thornshaped, about $1 / 2$ length of phallus.

Female. Unknown.

Diagnosis. This new species is very similar to C. conankinensis $(\mathrm{Ge}, 1992)$ and $C$. nankinensis (Razowski, 1964) morphologically, but $C$. subnomadana sp. n. can be distinguished by the phallus bearing only one cornutus in the male genitalia. In the latter two species, the phallus has two cornuti. The male genitalia of $C$. subnomadana are similar to those of $C$. nomadana (Erschoff, 1874), but those of C. subnomadana can be distinguished by the rounded apex of the median process of the transtilla, which is truncated in C. nomadana (Razowsk, 1970: Pl. 45, Figs. $60_{1-2}$ ).

Distribution. China (Ningxia).

Etymology. The specific name is derived from the Latin prefix $s u b$-, and the name of the previous known species nomadana, showing the similarity of these two species.

\subsection{Newly recorded species for China}

\subsubsection{Cochylimorpha declivana (Kennel, 1901)}

Figs. 1b, 2b

Euxanthis declivana Kennel, 1901. Deutsche Entomologische Zeitschrift Iris, 13(1900): 243. TL: Russia (Amur, Pom-pejewka).

Stenodes declivana: Razowski, 1961. Polskie Pismo Entomologiczne, 31: 308.

Cochylimorpha declivana: Razowski, 1991. Acta Zoologica Cracoviensia, 34(1): 105.

Material examined. China: 1 ô, Kuankuoshui Nature Reserves, Suiyang County $\left(27^{\circ} 58^{\prime} \mathrm{N}\right.$, $\left.107^{\circ} 11^{\prime} \mathrm{E}\right)$, Guizhou Province, 1,500 m, 10.VIII.
2010, leg. Linlin Yang. (Genitalia slide No. SYH11472).

Diagnosis. Adult (Fig. 1b) with wingspan $14.5 \mathrm{~mm}$. This species is similar to $C$. jaculana (Snellen, 1883) morphologically, but C. declivana can be distinguished by the forewing ground color lighter from the base to inner margin of the median fascia than that from the outer margin of the median fascia to the apex; the tegumen without a process at the apex and the phallus having two cornuti in the male genitalia (Fig. 2b). In C. jaculana, the ground color of the forewing is uniform throughout; the tegumen has a process at the apex, and the phallus has one cornutus.

Distribution. China (Guizhou), Russia.

Notes. This species is recorded for the first time from China.

\subsubsection{Cochylimorpha halophilana clavana (Constant, 1888) Figs. 1c, 2c, 4a}

Conchylis clavana Constant, 1888 . Annales de la Société Entomologique de France, 6(8): 164. TL: France (Alpes Maritimes).

Stenodes clavana: Razowski, 1970. Cochylidae, in Amsel et al. (ed.), Microlepidoptera Palaearctica, 3(1): 132.

Cochylimorpha clavana: Razowski, 1991. Acta Zoologica Cracoviensia, 34(1): 104.

Cochylimorpha halophilana clavana: Huemer, 2000. Gortania Atti del Museo Friulano di Storia Naturale, 22: 289. Razowski, 2002. Tortricidae of Europe, Tortricinae and Chlidanotinae, 1: 40.

Material examined. China: $2 \hat{\jmath}, 1$, Xinjiang Uyghur Autonomous Region, Abudula, Tacheng County (46²6’ N, 8259'E), 5-22.VIII.1990, leg. Jinfu Li. (Genitalia slide Nos.: ZX07024 §ิ’, SYH11333 ふึ, SYH11344 O).

Diagnosis. Adult (Fig. 1c) with wingspan 16.0-20.0 mm. This species is similar to $C$. fuscimacula (Falkovitsh, 1963) superficially, but C. halophilana clavana can be distinguished by the sacculus without a terminal process and the phallus bearing one cornutus in the male genitalia (Fig. 2c); the ductus bursae gradually narrowed posteriorly and the corpus bursae covered with tiny spines in the female genitalia (Fig. 4a). In $C$. fuscimacula, the sacculus has a terminal process 
and the phallus lacks cornuti; the ductus bursae is gradually broadened posteriorly, and the corpus bursae lacks spines.

Distribution. China (Xinjiang), France.

Hostplant. Artemisia gallica (Razowski, 2002).

Notes. This species is recorded for the first time from China.

\subsubsection{Cochylimorpha meridiolana (Ragonot,} 1894) Figs. 1d, 2d, 4b

Conchylis meridiolana Ragonot, 1894. Annales de la Société Entomologique de France, 63: 196. TL: Transkaspien [Turkestan] (Tura).

Cochylis ochrostriana Kennel, 1899. Deutsche Entomologische Zeitschrift Iris, 12: 35. TL: Central Asia [Russia] (Turkestan, Ferghana). Stenodes meridiolana: Razowski, 1970. Cochylidae, in Amsel et al. (eds.), Microlepidoptera Palaearctica, 3(1): 158.

Cochylimorpha meridiolana: Razowski, 1991. Acta Zoologica Cracoviensia, 34(1): 105.

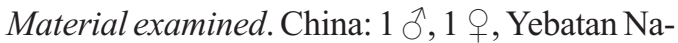
ture Reserves $\left(46^{\circ} 12^{\prime} \mathrm{N}, 82^{\circ} 59^{\prime} \mathrm{E}\right)$, Xinjiang Uyghur Autonomous Region, 8.-11.VII.1997. (Genitalia slide Nos.: SYH11098 क, SYH11109 đ).

Diagnosis. Adult (Fig. 1d) with wingspan 21.0-23.0 $\mathrm{mm}$. This species can be easily distinguished from its congeners by having a uniform forewing maculation. The male genitalia are similar to those of C. nankinensis (Razowski, 1964), but those of $C$. meridiolana can be differentiated by the median process of the transtilla gradually narrowed from the base to the apex, and the phallus lacking cornuti (Fig. 2d). In C. nankinensis, the median process of the transtilla is nearly semicircular, and the phallus has two cornuti. The female genitalia (Fig. 4b) are similar to those of $C$. jaculana (Snellen, 1883), but the corpus bursae lacks a circle of sclerotized band, which is present on the posterior 3/4 in C. jaculana.

Fig. 3. Male genitalia of Cochylimorpha spp.

- a. C. conankinensis (Ge), slide no. SYH11497.

- b. C. maleropa (Meyrick), slide no. SYH11381.

- c. C. razowskiana Kuznetzov, slide no. SYH11535.
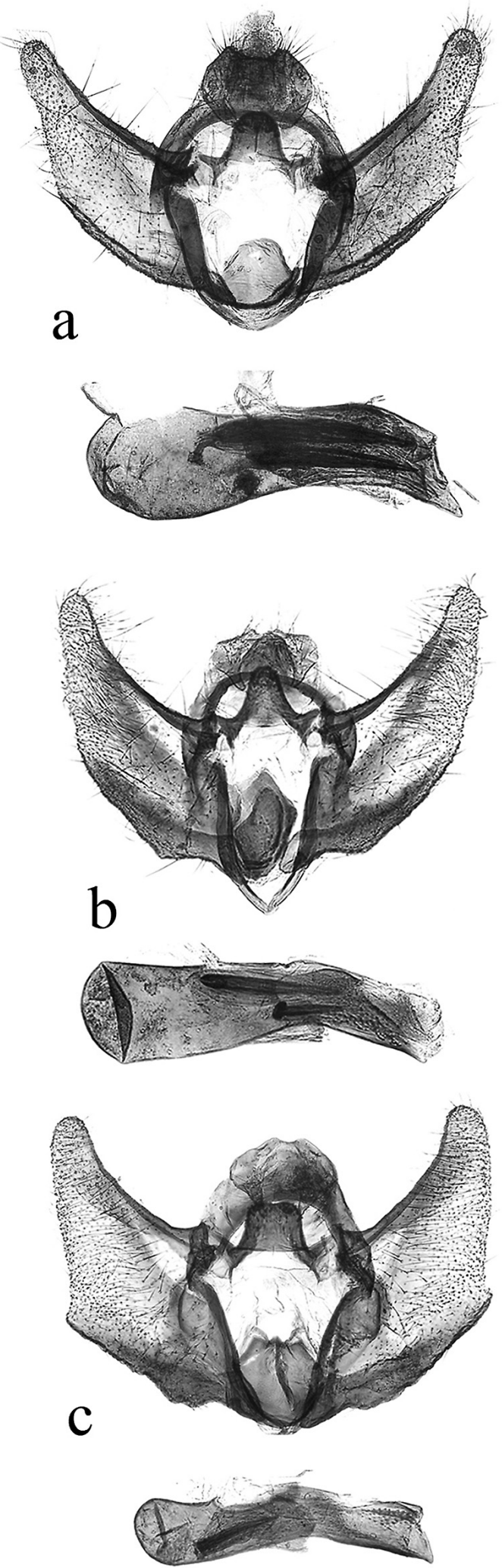
Distribution. China (Xinjiang), Russia, Turkestan.

Notes. This species is recorded for the first time from China.

\subsection{Three species with description of the female}

3.5.1. Cochylimorpha conankinensis (Ge, 1992) Figs. 1e, 3a, 4c

Stenodes conankinensis Ge, 1992. Sinozoologia, 9: 303. TL: China (Sichuan Province, Mt. Qingcheng).

Cochylimorpha conankinensis: Razowski, 2006. Nota Lepidopterologica, 29(1/2): 123.

Material examined. China: Sichuan Province: 1 q, Mt. Longquan, Chengdu City $\left(30^{\circ} 34^{\prime} \mathrm{N}\right.$, 104¹9’E), 850 m, 8.V.1994, leg. Jin Zhou. Shaanxi Province: 1 q, Huoditang Forest Farm, Ningshan County (33⒉ $\left.6^{\prime} \mathrm{N}, 108^{\circ} 26^{\prime} \mathrm{E}\right), 1,650 \mathrm{~m}$, 28.V.-2.VI.1992, leg. Houhun Li; 1 ㅇ, Shangdong, Ziyang County, Ankang City $\left(32^{\circ} 33^{\prime} \mathrm{N}\right.$, $108^{\circ} 32^{\prime}$ E), 300 m, 22.V.1994, leg. Jin Zhou; 3 స̄ô, Louguantai, Zhouzhi County, Xi'an City

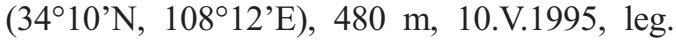
Aisihaer. Gansu Province: 1 d, Yangba Forest Farm, Kang County ( $\left.33^{\circ} 20^{\prime} \mathrm{N}, 105^{\circ} 36^{\prime} \mathrm{E}\right), 800$ m, 6.VI.1995, leg. Aisihaer; Wen County

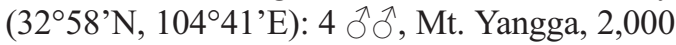
m, 4.-5.VII.2001, 1 సे, Qiujiaba, 2,350 m, 3.VII.2001, leg. Houhun Li and Xinpu Wang. (Genitalia slide Nos.: MZ96142 §, MZ96143 , Zhang Xu NKU3, ZX06053 ô, ZX06059 ô, ZX06060 ㅇ, SYH11482 ô, SYH11497 ô, SYH12043 +, SYH12070 ふ).

Description. Adult (Fig. 1e) with wingspan $13.0-18.0 \mathrm{~mm}$. Forewing in male narrower than that in female.

Female genitalia (Fig. 4c). Papilla analis narrow, length about six times width, slightly shorter than apophysis posterioris. Apophysis posterioris slightly shorter than apophysis anterioris. Sterigma weakly sclerotized, nearly quadrate. Antrum annular, somewhat short, heavily sclerotized, serrate on posterior margin; ductus bursae very short, about $1 / 6$ length of corpus bursae, membranous, length slightly longer than width. Corpus bursae nearly rounded, heavily scleroti- zed, densely covered with tiny spines; ductus seminalis arising from posterior part of corpus bursae.

Diagnosis. This species is similar to C. nankinensis (Razowski, 1964) in both fascies and genital structures, but $C$. conankinensis can be distinguished by the phallus with two straight cornuti in the male genitalia (Fig. 3a). In C. nankinensis, the phallus has one straight cornutus and one undulate cornutus. The female genitalia can be easily distinguished from its congeners by the corpus bursae entirely covered with dense tiny spines. This species is also similar to $C$. maleropa (Meyrick, 1937) in genital structures, and the differences between them are noted under the latter species.

Distribution. China (Gansu, Shaanxi, Sichuan).

Notes. The female of this species is described for the first time. This species appeared as a synonym of C. isocornutana (Razowski, 1964) in Razowski (2009). We treat it as a valid species since the adults of the two species look very different.

3.5.2. Cochylimorpha maleropa (Meyrick, 1937) Figs. 1f, g, 3b, 4d

Euxanthis maleropa Meyrick, 1937. In Caradja \& Meyrick, Deutsche Entomologische Zeitschrift Iris, 51: 172. TL: China (Yunnan Province, Likiang).

Stenodes maleropa: Razowski, 1970. Cochylidae, in Amsel et al. (ed.), Microlepidoptera Palaearctica, 3(1): 167.

Cochylimorpha maleropa: Razowski, 1991. Acta Zoologica Cracoviensia, 34(1): 105.

Material examined. China: Yunnan Province: 1 + , Yufengsi, Lijiang ( $\left.26^{\circ} 52^{\prime} \mathrm{N}, 100^{\circ} 14^{\prime} \mathrm{E}\right), 2,650$ $\mathrm{m}$, 17.VII.2001, leg. Houhun Li and Xinpu Wang. Shaanxi Province: 1 d, Huoditang Forest Farm, Ningshan County $\left(33^{\circ} 26^{\prime} \mathrm{N}, 108^{\circ} 26^{\prime} \mathrm{E}\right)$, 1,620 m, 10.VI.1987, leg. Houhun Li; 1 , Xinjiashan Forest Farm, Feng County $\left(33^{\circ} 55^{\prime} \mathrm{N}\right.$, $\left.106^{\circ} 31^{\prime} \mathrm{E}\right), 1,600 \mathrm{~m}, 13 . \mathrm{VII} .1988$, leg. Houhun Li. (Genitalia slide Nos.: SYH11258 + , SYH11381 ふ).

Description. Adult (Fig. 1f-g) with wingspan 7.0-14.0 mm. 


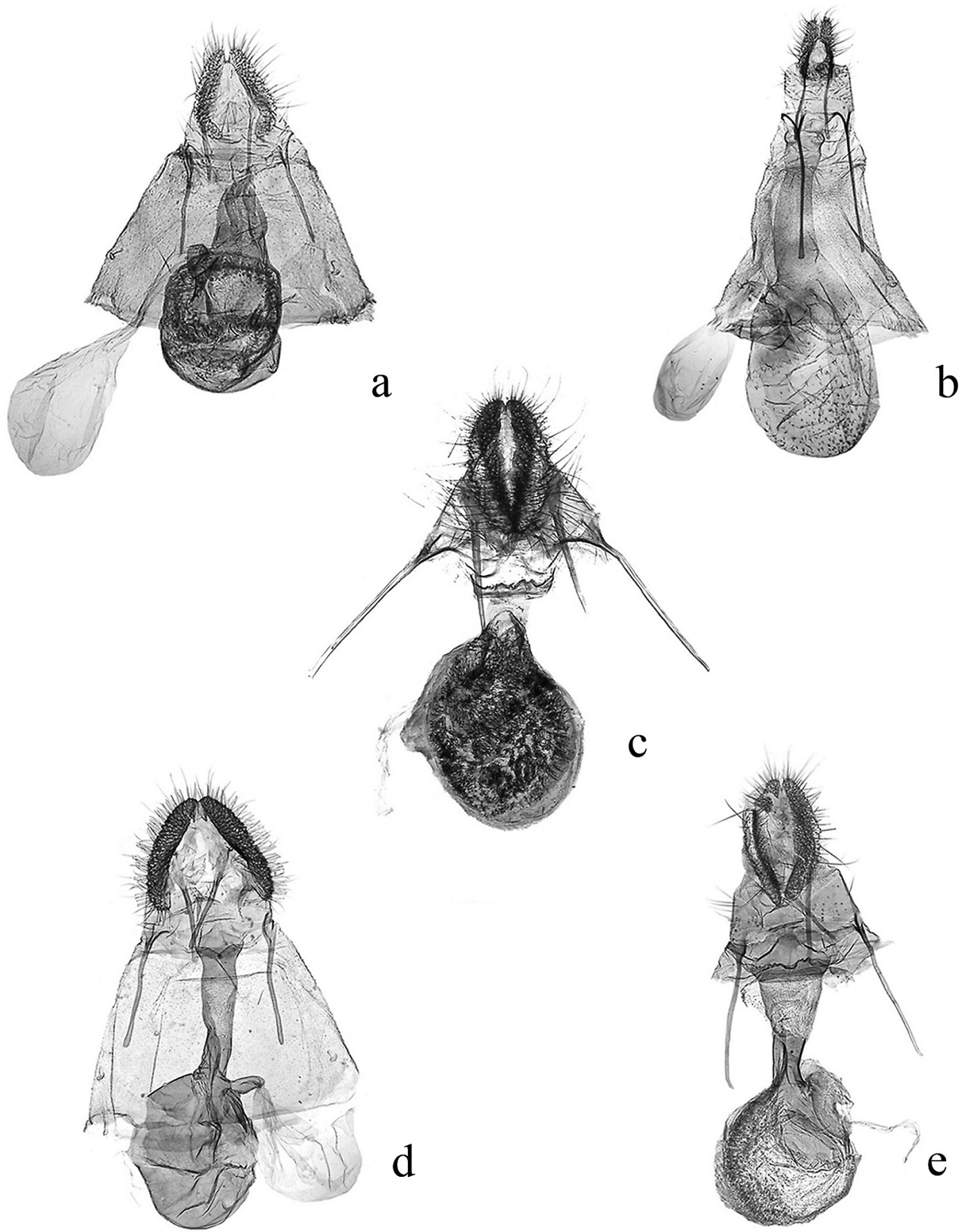

Fig. 4. Female genitalia of Cochylimorpha spp. - a. C. halophilana clavana (Constant), slide no. SYH11344. - b. C. meridiolana (Ragonot), slide no. SYH11098. - c. C. conankinensis (Ge), slide no. SYH12043. - d. C. maleropa (Meyrick), slide no. SYH11258. - e. C. razowskiana Kuznetzov, slide no. SYH11269.

Female genitalia (Fig. 4d). Papilla analis narrow, length about six times width, about the same length as apophysis posterioris. Apophysis posterioris slightly shorter than apophysis anterioris. Ductus bursae weakly sclerotized, slightly shorter than corpus bursae, length about 3.5 times 
width, slightly notched on posterior margin. Corpus bursae nearly rounded, weakly sclerotized; ductus seminalis arising from posterior part of corpus bursae.

Diagnosis. The male genitalia of this species are similar to those of $C$. conankinensis (Ge, 1992), but $C$. maleropa can be distinguished by the sacculus slightly protruded at the middle on the ventral margin, and the phallus bearing two cornuti unequal in length in the male genitalia (Fig. 3b); and the ductus bursae slightly shorter than the spine-free corpus bursae in the female genitalia. In C. conankinensis, the sacculus does not protrude ventrally and the phallus has two cornuti equal in length; the ductus bursae is about $1 / 6$ length of the corpus bursae and the corpus bursae is densely covered with tiny spines. This species is also similar to $C$. razowskiana Kuznetzov, 2005, and the differences between them are noted under the latter species.

Distribution. China (Shaanxi, Yunnan).

Variation. In males from Shaanxi, the broad subapical fascia on the forewing is grayish brown mixed with yellowish brown, and extends from the anterior half of the outer margin of the median fascia obliquely to the tornus, forming a yellow triangular patch on the dorsum between the median fascia and the subapical fascia (Fig. 4).

Notes. The female of this species is described for the first time.

\subsubsection{Cochylimorpha razowskiana Kuznetzov, 2005 Figs. 1h, 3c, 4e}

Stenodes pallens Kuznetzov, 1966. Trudy Zoologicheskogo Instituta Akademii Nauk SSSR, 37: 202. TL: Russia (Primorsky Krai, Vladivostok, Okeanskaja).

Cochylimorpha pallens: Razowski, 1991. Acta Zoologica Cracoviensia, 34(1): 106.

Cochylimorpha razowskiana Kuznetzov, 2005. Zoosystematica Rossica, 14(1): 178.

Material examined. China: Hebei Province: 2

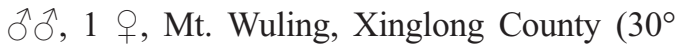
36’N, 117²9'E), 2.-3.VII.2009, leg. Qing Jin. Shanxi Province: 1 , Mt. Luya, Ningwu County (39 $\left.00^{\circ} \mathrm{N}, 112^{\circ} 18^{\prime} \mathrm{E}\right), 1,450 \mathrm{~m}, 19 . \mathrm{VII} .2011$, leg. Shulian Hao and Jiayu Liu. Henan Province: 1 ${ }^{\top}$, Shiziping, Lushi County $\left(34^{\circ} 03^{\prime} \mathrm{N}, 111^{\circ} 02^{\prime} \mathrm{E}\right)$,
1,000 m, 30.V.2000, leg. Haili Yu. Shaanxi Province: 2 $\widehat{\jmath}, 1$ q, Xinjiashan Forest Farm, Feng County $\left(33^{\circ} 55^{\prime} \mathrm{N}, 106^{\circ} 31^{\prime} \mathrm{E}\right), 1,600 \mathrm{~m}, 10$ 13.VII.1988, leg. Houhun Li; 1 $\hat{\jmath}$, Huoditang, Ningshan County (3326'N, $\left.108^{\circ} 26^{\prime} \mathrm{E}\right), 1,620 \mathrm{~m}$, 13.VII.1990, leg. Jinfu Li; 1 q, Xunyangba, Ningshan County $\left(33^{\circ} 43^{\prime} \mathrm{N}, 108^{\circ} 50^{\prime} \mathrm{E}\right), 1,360 \mathrm{~m}$, 3.VII.2007, leg. Haili Yu. Gansu Province: 11 $\delta^{\lambda}$, Mt. Yangga, Wen County $\left(32^{\circ} 58^{\prime} \mathrm{N}\right.$, $\left.104^{\circ} 41^{\prime} \mathrm{E}\right), 2,000$ m, 5.VII.2001, leg. Houhun Li

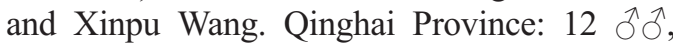
Mengda, Xunhua (35 $\left.50^{\circ} \mathrm{N}, 102^{\circ} 28^{\prime} \mathrm{E}\right), 2,240 \mathrm{~m}$, 13.VII.1995, leg. Houhun Li and Shuxia Wang. Ningxia Hui Autonomous Region: Mt. Liupan

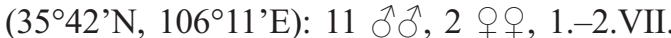
2008,1 으, Woyangchuan Forest Farm ( $35^{\circ} 42^{\prime} \mathrm{N}$, $\left.106^{\circ} 11^{\prime} \mathrm{E}\right), 1,700 \mathrm{~m}$, 3.VII.2008, leg. Shulian Hao and Zhiwei Zhang. (Genitalia slide Nos.:

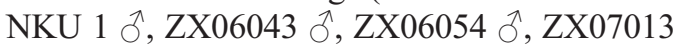

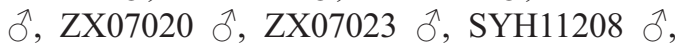
SYH11269 क, SYH11347 ô, SYH11478 ô, SYH11526 ㅇ, SYH11527 ㅇ, SYH11532 ô,

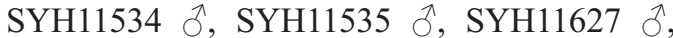
SYH12074 क, SYH12078 ô, SYH12081 ô, SYH12082 ㅇ).

Description. Adult (Fig. 1h) with wingspan 9.0-16.0 mm.

Female genitalia (Fig. 4e). Papilla analis narrow, length about six times width, slightly longer than apophysis posterioris. Apophysis posterioris about 5/7 length of apophysis anterioris. Sterigma weakly sclerotized, nearly quadrate. Antrum annular, somewhat short, serrated on posterior margin; ductus bursae gradually broadened posteriorly, slightly shorter than corpus bursae, its anterior half weakly sclerotized, posterior half membranous. Corpus bursae nearly rounded, densely covered with tiny spines laterally, sclerotized on posterior half laterally; ductus seminalis arising from posterior part of corpus bursae.

Diagnosis. The male genitalia of this species are similar to those of C. maleropa (Meyrick, 1937 ) with the sacculus protruded outward ventrally, but those of $C$. razowskiana can be distinguished by the nearly quadrate median process of the transtilla in the male genitalia (Fig. 3c); the ductus bursae gradually broadened posteriorly and the corpus bursae covered with tiny spines in the female genitalia. In $C$. maleropa, the median 
process of the transtilla is semioval; the ductus bursae is uniformly thick and the corpus bursae lacks spines.

Distribution. China (Beijing, Gansu, Hebei, Henan, Ningxia, Qinghai, Shaanxi, Shanxi), Russia.

Notes. The female of this species is described for the first time.

Acknowledgments. We express our thanks to Dr. Józef Razowski (Kraków) and Dr. Peter Huemer (Innsbruck) for providing some literature. Special thanks are given to Dr. John Brown (Washington, DC) and an anonymous reviewer for their valuable comments. This study was partly supported by the National Natural Science Foundation of China (No. 30930014 and No. J1210005).

\section{References}

Aarvik, L. 2010: Review of East African Cochylini (Lepidoptera, Tortricidae) with description of new species. - Norwegian Journal of Entomology 57: 81-108.

Bai, J. W., Guo, S. \& Guo, M. J. 1996: New species of Cochylidae from China (Lepidoptera). - Acta Entomologica Sinica 39(2): 191-195.

Brown, J. W. 2005: Tortricidae (Lepidoptera). — In: World catalogue of insects. Vol. 5. Apollo Books, Stenstrup, $741 \mathrm{pp}$.

Constant, A. 1888: Descriptions de Lépidoptères nouveaux ou peu connus. - Annales de la Société Entomologique de France 6(8): 161-172 + pl. 4. Paris.

Ge, X. S. 1992: Study on the Chinese Stenodes Guenée (Lepidoptera: Cochylidae) with descriptions of new species. - Sinozoologia 9: 299-306.

Gilligan, T. M., Baixeras, J., Brown, J. W. \& Tuck, K. R. 2012: T@RTS: Online World Catalogue of the Tortricidae (Ver. 2.0). Available at http://www.tortricid. net/catalogue.asp. (Site visited on 24 January, 2013).

Guenée, A. M. 1845: Essai sur une nouvelle classification des Microlépidoptères et catalogue des espèces europeennes connues jusqú à jour. - Annales de la Société Entomologique de France 3(2): 105-192, 207-344.

Huemer, P. 2000: Cochylimorpha halophilana adriatica ssp. n., a remarkable new Tortricidae from Friuli-Venezia Giulia (Italy) (Lepidoptera). — Gortania Atti del Museo Friulano di Storia Naturale 22: 283-290.

Kennel, J. 1899: Neue Wickler des palaearctischen Gebietes. - Deutsche Entomologische Zeitschrift Iris 12(1): 1-43.

Kennel, J. 1901: Neue Wickler des palaearctischen Gebietes. - Deutsche Entomologische Zeitschrift Iris 13(1900): 205-305.

Kuznetzov, V. I. 1966: New species of leaf-rollers (Lepidoptera, Tortricidae) from south of the Primorye terri- tory. - Trudy Zoologicheskogo Instituta Akademii Nauk SSSR 37: 177-207.

Kuznetzov, V. I. 2005: Cochylimorpha razowskiana nom. n. for C. pallens (Kuznetzov, 1966) (Lepidoptera: Cochylidae). - Zoosystematica Rossica 14(1): 178.

Liu, Y. Q. \& Li, G. W. 2002: Fauna Sinica, Insecta. Vol. 27, Lepidoptera Tortricidae. - Chinese Science Press, Beijing. 463 pp.

Li, H. H. 2002: Gelechiidae of China (I). - Tianjin: Nankai University Press, xvii +538 pp.

Meyrick, E. 1937: In: Caradja, A. \& Meyrick, E., 1937. Materialien zu einer Microlepidopteren-Fauna des Yülingshanmassivs (Provinz Yünnan). — Deutsche Entomologische Zeitschrift Iris 51: 137-182.

Ragonot, E. L. 1894: Notes synonimiques sur des Microlépidoptères et descriptions d'espèces peu connues ou inédites. - Annales de la Société Entomologique de France 63: 161-226, Taf. 1. Paris.

Razowski, J. 1959: Uwagi o rodzinie Phaloniidae (Lepidoptera). - Polskie Pismo Entomologiczne 29: 437 446.

Razowski, J. 1960: Studies on the Cochylidae (Lepidoptera). Part II. The genera of the Palaearctic Cochylidae. - Polskie Pismo Entomologiczne 30: 281-356.

Razowski J. 1961: Studies on Cochylidae (Lepidoptera). Part VI. Remarks on types of some Cochylidae. Polskie Pismo Entomologiczne 31: 301-319.

Razowski J. 1964: Studies on the Cochylidae (Lepidoptera). Part IX. Revision of Caradja's collection with descriptions of new species. - Acta Zoologica Cracoviensia, 9(4): 337-354.

Razowski, J. 1970: Cochylidae. In: Amsel, H. G., Gregor, F. \& Reisser, H. (eds.), Microlepidoptera Palaearctica. Vol. 3. (Wien), IV + 528 pp., 161 pls.

Razowski, J. 1977: New Cochylidae (Lepidoptera) from Dr. Issiki collection. Transactions of the Lepidopterological Society of Japan 28(1): 357.

Razowski, J. 1987: The genera of Tortricidae (Lepidoptera). Part I: Palaearctic Chlidanotinae and Tortricinae. Acta Zoologica Cracoviensia 30(11): 14155.

Razowski, J. 1991: The catalogue of the species of Tortricidae (Lepidoptera). Part I: Palaearctic Chlidonatinae and Tortricidae: Cochylini, Tortricini, Ceracini, Cnephasiini. Acta Zoologica Cracoviensia 34(1): 9962.

Razowski, J. 2002: Tortricidae of Europe. Vol. 1. Tortricinae and Chlidanotinae. Frantisek Slamka, Bratislava. $241 \mathrm{pp}$.

Razowski, J. 2005: Descriptions and rectifications in Asian Cochylini (Lepidoptera: Tortricidae). Polskie Pismo Entomologiczne 74(4): 43138.

Razowski, J. 2006: Notes on Cochylimorpha Razowski, 1959 with description of one new species from Tibet (Tortricidae). Nota Lepidopterologica 29(1/2): 121 24.

Razowski, J. 2009: Cochylini. In: Tortricidae of the Palaearctic Region. Vol. 2 Published by Franti k Slamka, Krak-Bratislava, 195 pp. 